\title{
An Economy-Wide Assessment of Artificial Intelligence Investment on Manufacturing: A Case Study of Taiwan's Semiconductor and ICT Industries
}

\author{
Yu-Hsien Chu ${ }^{1}$, Sheng-Ming Hsu' ${ }^{2}$, Ching-Cheng Chang ${ }^{3}$, Shih-Hsun Hsu' ${ }^{1}$ \\ ${ }^{1}$ Department of Agricultural Economics, National Taiwan University, Taiwan \\ ${ }^{2}$ Department of Applied Economics, National Chung Hsing University, Taiwan \\ ${ }^{3}$ Institute of Economics, Academia Sinica, Taiwan \\ Email: d98627006@ntu.edu.tw, donnyhsu1978@gmail.com,emily@econ.sinica.edu.tw,m577@ntu.edu.tw
}

How to cite this paper: Chu, Y.-H., Hsu, S.-M., Chang, C.-C., \& Hsu, S.-H. (2020). An Economy-Wide Assessment of Artificial Intelligence Investment on Manufacturing: A Case Study of Taiwan's Semiconductor and ICT Industries. Modern Economy, 11, 1040-1052.

https://doi.org/10.4236/me.2020.115078

Received: April 4, 2020

Accepted: May 12, 2020

Published: May 15, 2020

Copyright () 2020 by author(s) and Scientific Research Publishing Inc. This work is licensed under the Creative Commons Attribution International License (CC BY 4.0).

http://creativecommons.org/licenses/by/4.0/ (c) (i) Open Access

\begin{abstract}
With the rapid development of digital computing capabilities, the emergence of Internet of Things (IoT), cloud and big data analytics, Artificial Intelligence (AI) has become an important innovative tool for digital transformation and technological upgrading of global manufacturing. In this paper, using dynamic Computable General Equilibrium (CGE) model of MONASH-type and Taiwan's input-output tables to capture the supply-chain interdependence and resource constraints, we present the economy-wide assessment of government policies and private companies' investment in smart manufacturing, as well as the impact on the output and employment of Taiwan semiconductor and ICT industry. Simulation results show that, under increasing AI investment, semiconductor output will be $10.34 \%$ higher than the baseline, and employment demand will be $24.61 \%$ lower than the baseline in 2025 . The result is similar on the ICT industry as well. The development of smart manufacturing is an adaptation strategy for private enterprises to cope with declining birthrate, labor shortage, and improving production yield and efficiency. At the same time, the unemployment and the uneven income distribution may be the side effect while developing the AI on manufacturing. It is suggested that in addition to focusing on AI talent cultivation and the establishment of the infrastructures, the government may also adopt fiscal and tax policies to improve the income distribution and strengthen the labor transfer.
\end{abstract}

\section{Keywords}

Artificial Intelligence, Smart Manufacturing, Input-Output Tables, Computable General Equilibrium Model (CGE) 


\section{Introduction}

With the rapid development of digital computing capabilities, the emergence of Internet of Things (IoT), cloud and big data analytics, Artificial Intelligence (AI) has become an important innovative tool for digital transformation and technological upgrading of global manufacturing. At the same time, the advent of the fifth generation $(5 \mathrm{G})$ of mobile communication technology accelerates the promotion and development of AI. AI's major economic effect is the automation of tasks that could not be automated before (e.g., optimizing production processes or decision making through big data analysis and machine learning). Like past waves of innovation, AI will create both benefits (e.g., productivity growth) and costs (e.g., job losses, income inequality). Governments and private sectors should understand its potential impacts so that policies and operations can be put in place to scale up the benefits of AI, while mitigating the costs.

Although AI has a wide range of applications in industries, most of the economic research on AI focused on its impacts on employment, wages, and productivity. Graetz and Michaels (2018) used robot shipment data from the International Federation of Robotics (IFR) from 17 countries and found that robots accounted for one-tenth of GDP growth in these countries where productivity growth increased by more than 15\% from 1993 to 2007. The study also found that average wages increased with the use of robots, but lower working hours for low- and intermediate-skilled workers. Dauth et al. (2017) integrated labor market data of Germany and the use of robots in manufacturing and service industries surveyed by the IFR from 1994 to 2014 . They found that each additional industrial robot would result in the loss of two manufacturing jobs. However, the service industry has created enough new jobs to offset or compensate more employment in some cases.

In the United States, Frey and Osborne (2017) combined machine learning methods and the Standard Occupational Classification established by the U.S. Bureau of Labor Statistics to build a computerized probability prediction model for non-repetitive jobs to determine which jobs were easily replaced by robots. The study found that $47 \%$ of jobs were at high risk of automation, and suggested that different labor markets may be at high, medium, or low risk of automation. However, they did not analyze possible labor savings and potential productivity growth. Acemoglu and Restrepo (2019) studied the regional labor market from 1990 to 2007 and found that the adoption of industrial robots was negatively correlated with employment and wages in the U.S. They estimated that each additional robot would reduce the employment of 6 workers, and reduce wages by $0.5 \%$ for an additional robot per 1000 workers. Their study also found the effect was most obvious in manufacturing sector especially in traditional craftsmanship and blue-collar workers without university degree.

However, so far there was almost no economy-wide assessment on the ecosystem of AI to enhance our capacity to understand the forces transforming our industries and society. In Asia, Taiwan has rapidly been catching up to the global 
AI wave. The government has rolled out the AI Taiwan Action Plan in 2018, a comprehensive industrial plan to accelerate innovation and development. During the same time Taiwan's Asia Silicon Valley Development Plan was also launched in order to incorporate AI into areas like transportation, healthcare, telecommunications, logistics, and other smart city initiatives. Compared with other Asian countries, Chinese Taipei has two advantages, industrial environment and AI talent ${ }^{1}$, leaving ample opportunities for manufacturing companies to capitalize on the growing integration of hardware and software. Therefore, this study intends to focus on Taiwan's manufacturing supply chain by using a dynamic CGE model of MONASH-type and Input-Output (IO) database to evaluate the economic impacts of the AI development plans in Taiwan.

Moreover, because Taiwan has the relatively matured semiconductor and Information and Communication Technology (ICT) industry supply chain, this study will also explore how the increasing use of AI will affect the upstream, middle-stream and down-stream networks and impact the whole economy. Over the past sixty years, semiconductors have led to the rapid development of global technology in electronics, computers, and ICT such as smartphones which has greatly changed human life $e^{2}$. Today, most of technology devices are based on semiconductor and controlled by programming applications to perform different functions. The demand for the development of key semiconductor technologies and the supply of components is increasing. With vertical specialization and industrial clustering, Taiwan's semiconductor and ICT industries have become major partners of international brand manufacturers and highly competitive globally. With efficient and flexible production, Taiwan's production value of semiconductor ranks second in the world, of which the wafer foundry production value ranks first in the world (market share $72.2 \%$ ), IC design production value ranked second in the world (market share 17.2\%), packaging and testing output value globally ranked first (market share 55.9\%) (Smart Electronics Industry Project Promotion Office, 2019).

Besides the introductory remarks provided in Section 1, Section 2 will explain the CGE methodology used in this study and three scenario designs for policy simulations. Section 3 demonstrates and discusses simulation results. The final section concludes our research results and provides some policy suggestions for AI development policy in Taiwan.

\section{Methodology}

Although AI has a wide range of applications, it is not only a key component of future smart technologies but also a new opportunity for the next generation of semiconductor and the ICT industries. However, there is no systematic impact ${ }^{1}$ In terms of AI talent pool, Taiwan produces every year sizable graduates of computer-science degrees and electrical engineers that, if properly up skilled, can provide incredible value to the AI community.

${ }^{2}$ The applications of semiconductor include smart phones, automobiles, networks, cloud data, industrial automation, smart homes and various consumer electronics products. 
assessment on the AI ecosystem using Input-Output (IO) models or Computable General Equilibrium (CGE) analyses.

There are two main reasons to use CGE models for policy simulation and economic impact assessment in this study. One is the consideration of the economy-wide impact assessment should use the supply chain or systemic analysis method. Secondly, in order to yield realistic simulation results and to capture the opportunity costs of limited resources (such as lack of labor, water, land, etc.), the prices should be endogenously determined. The main difference between the CGE models and the IO models is that the former is based on the general equilibrium theory of the neoclassical school and integrates all sectors or stakeholders in the economy (such as industry, households, government, import and export, etc.). The IO relationships are embedded in the CGE model, covering various economic activities such as production, demand, trade, employment, and income in an economy, and fully reflected through the price endogenization mechanism. The opportunity cost of limited resources, such as labor, land, and water, are determined by the demand and supply.

The General Equilibrium Model for Taiwanese Economy and Environment (GEMTEE) model used in this study was jointly developed by the Center for Sustainability Science of the Academia Sinica and the Australian Bureau of Agriculture, Resources and Economics (ABARES) (Chang et al., 2018). It is based on the Monash dynamic computable general equilibrium model, and expanded through investment and population dynamics mechanisms (Dixon \& Parmenter, 1996; Dixon \& Rimmer, 2002). Based on the IO database and macroeconomic projections from the expert forecasting organizations, long-term baseline forecasting can be performed (Dixon \& Rimmer, 2009). The basic structure is illustrated in Figure 1 (Chang et al., 2018). The main sub-modules include taxation, economy, population, society, environment, and energy. GEMTEE can

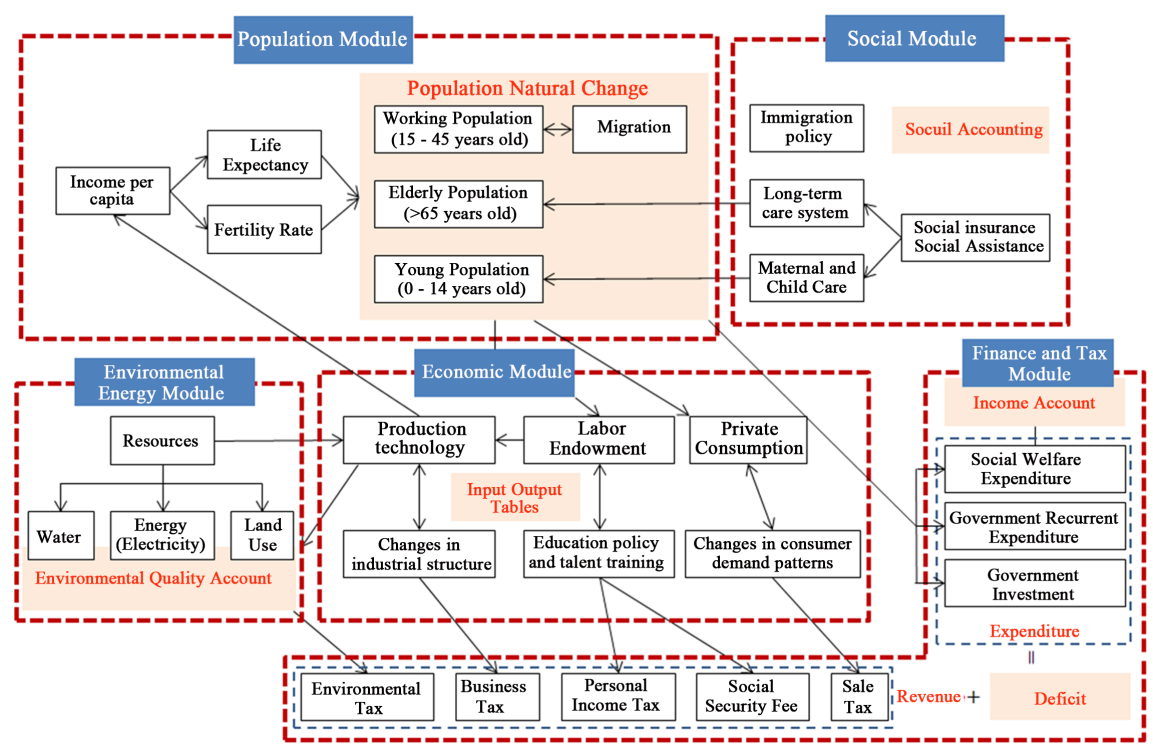

Figure 1. The basic structure of GEMTEE. Source: Chang et al. (2018). 
be used to provide an assessment of the impact of the government's expansion of public investment expenditure on Taiwan's macro-economy, finance and income distribution (Liou et al., 2018). It can also be used to provide the trend analysis of population growth and long-term care demand in Taiwan (Chen et al., 2020).

The two main dynamic mechanisms in GEMTEE are population growth and investment. The dynamic investment adjustment mechanism is an endogenous adjustment mechanism. The net capital stock and the new investment accumulated in one period will become the capital stock available for industrial production in the next period (Hsu et al., 2006). The population module mainly describes the component of population changes by gender and age groups that occur over time through the interplay of three demographic processes: fertility, mortality, and migration (Lin et al., 2015; Chen et al., 2015).

For the design of simulation scenarios, this study follows the "Taiwan AI Action Plan (Year 2018 to 2021)" prepared by the government and focuses on Taiwan's semiconductors and ICT industries. Secondly, many private companies also invest in smart manufacturing based on their needs. In order to design more reasonable scenarios, we also interviewed a number of industry experts to provide their companies' experience and suggestions when investing in smart manufacturing. Therefore, three scenarios are summarized in Table 1 based on the official data and industry experts' projections.

Before the assessment, this study used GEMTEE to predict Taiwan macro-economy and individual industries from 2015 to 2025 as the baseline projection. In addition, this study also uses historical simulation from 2011 to 2015 to calibrate the rate of technological progress and then this technological growth rate is treated exogenously in the 2016 to 2025 baseline projection. The results of policy impacts are illustrated by the differences of the policy simulation results from the baseline projection. The relationship between historical simulations, baseline projection, and policy simulations is shown as Figure 2.

In this study, GEMPACK (General Equilibrium Modeling PACK age) software is used to solve the GEMTEE. GEMPACK has been designed to automate the solution of large-scale economic models and contains the capacities for solving

Table 1. The baseline and scenario setting.

\begin{tabular}{|c|c|c|c|}
\hline Scenario & Content & Demand-side Setting & $\begin{array}{c}\text { Supply-side Setting } \\
\text { (In some industries, by 2025) }\end{array}$ \\
\hline Baseline & $\begin{array}{l}\text { - To observe the rate of technical pro } \\
\text { - To use this rate to carry out econon }\end{array}$ & $\begin{array}{l}\text { ss through the historical data from } 2011 \text { to } 2015 \text {. } \\
\text { simulation estimates for 2016-2025. }\end{array}$ & \\
\hline Scenario 1 & The effect of government policies only. & Investment of USD 600 million in 4 to 5 years & $\begin{array}{l}-\quad+30 \% \text { labor efficiency } \\
-\quad+3 \% \text { technical efficiency }\end{array}$ \\
\hline Scenario 2 & The effect of private investment only. & Investment of USD 300 million in 2 to 3 years & $\begin{array}{l}-\quad+40 \% \text { labor efficiency } \\
\text { - } \quad+4 \% \text { technical efficiency }\end{array}$ \\
\hline Scenario 3 & $\begin{array}{l}\text { The effect of public and } \\
\text { private investment together. }\end{array}$ & Investment of USD 900 million in 4 to 5 years & $\begin{array}{l}-\quad+50 \% \text { labor efficiency } \\
\text { - } \quad+5 \% \text { technical efficiency }\end{array}$ \\
\hline
\end{tabular}

Source: This study. 


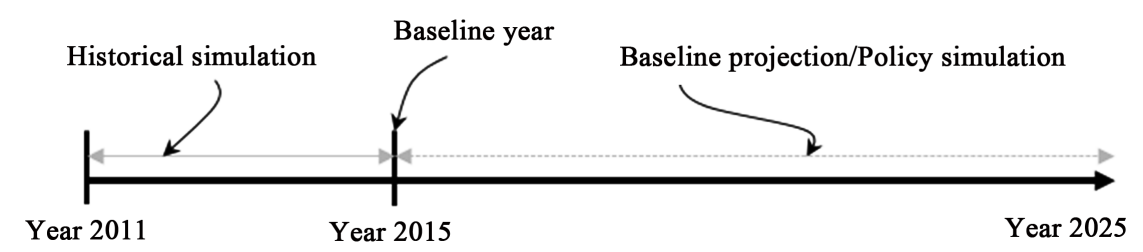

Figure 2. The relationship between historical simulations, baseline projection, and policy simulations in this study.

recursive-dynamic and fully inter-temporal CGE models (Harrison \& Pearson, 1996). It provides a computer-assisted method of converting GEMTEE equations into a tailor-made computer program and then produces accurate solutions.

\section{Research Results and Discussion}

Taiwan's semiconductor and ICT industry has an irreplaceable position in the world. In the process of industrial upgrading and transformation, AI will bring revolutionary innovations into the industry. The "Taiwan AI Action Plan" focused on injecting greater momentum to the industry and helping private companies invest in AI technology to improve production efficiency, reduce operating costs and induce domestic industry growth. Therefore, this study targets 170 industrial sectors in the input-output table compiled by the Directorate General of Budget, Accounting and Statistics (DGBAS) for an economy-wide assessment (Directorate-General of Budget, Accounting and Statistics, 2014a, 2014b, 2014c). However, we focus on the AI impact on production value and employment of the semiconductor and ICT industry that are more related to the Taiwan AI Action Plan. Table 2 and Table 3 show the simulation results.

The simulation results in Table 2 show that in the production value, without considering government and private investment in AI (baseline scenario), it is expected to grow by $0.5 \%$ to $1.1 \%$ every year from 2020 to 2025 . Under private investment (Scenario 3), the semiconductor production value is expected to exceed USD 100 billion by 2025, which is 10.34 percentage points higher than the baseline. The impact of the production value of Scenario 1 will be greater than that of Scenario 2 due to the cultivation of AI talents and the deployment of AI infrastructure from government policies in Scenario 1. On the other hand, the investment by individual companies is short-term and most of them are the construction of production line automation or smart storage and logistics. Therefore, its impact is not so big as that in Scenario 1.

In Table 3, it can be seen that Taiwan's semiconductor industry employs more than 132,000 people. Without considering government and private investment in AI (baseline), it is expected that the annual employment will decrease, a reduction of $0.32 \%-1.57 \%$. So the baseline result implies that the industry employment will be reduced to 127,500 in 2025 . In recent years the semiconductor industry has actively promoted smart factories. Simulation results of Scenario 3 show that under the promotion of government policies and private investment, it is estimated that the employment in the semiconductor industry 
Table 2. The production value impacts of smart manufacturing on Taiwan's semiconductor and ICT industry.

\begin{tabular}{|c|c|c|c|c|c|c|c|c|c|c|c|c|c|c|c|c|}
\hline \multirow[b]{2}{*}{ Sector } & \multirow[b]{2}{*}{ Scenario } & $\begin{array}{l}\text { Year } \\
2015\end{array}$ & \multicolumn{2}{|c|}{$\begin{array}{l}\text { Year } \\
2019\end{array}$} & \multicolumn{2}{|c|}{$\begin{array}{l}\text { Year } \\
2020\end{array}$} & \multicolumn{2}{|c|}{$\begin{array}{l}\text { Year } \\
2021\end{array}$} & \multicolumn{2}{|c|}{$\begin{array}{l}\text { Year } \\
2022\end{array}$} & \multicolumn{2}{|c|}{$\begin{array}{l}\text { Year } \\
2023\end{array}$} & \multicolumn{2}{|c|}{$\begin{array}{l}\text { Year } \\
2024\end{array}$} & \multicolumn{2}{|c|}{$\begin{array}{l}\text { Year } \\
2025\end{array}$} \\
\hline & & $\begin{array}{c}\text { Base } \\
\text { Year } \\
\text { (USD } \\
\text { million) }\end{array}$ & $\begin{array}{c}\text { YOY } \\
(\%)\end{array}$ & $\begin{array}{c}\text { Diff. } \\
\text { from } \\
\text { baseline } \\
\text { (ppt) }\end{array}$ & $\begin{array}{l}\text { YOY } \\
(\%)\end{array}$ & $\begin{array}{c}\text { Diff. } \\
\text { from } \\
\text { baseline } \\
\text { (ppt) }\end{array}$ & $\begin{array}{c}\text { YOY } \\
(\%)\end{array}$ & $\begin{array}{c}\text { Diff. } \\
\text { from } \\
\text { baseline } \\
\text { (ppt) }\end{array}$ & $\begin{array}{l}\text { YOY } \\
(\%)\end{array}$ & $\begin{array}{c}\text { Diff. } \\
\text { from } \\
\text { baseline } \\
\text { (ppt) }\end{array}$ & $\begin{array}{l}\text { YOY } \\
(\%)\end{array}$ & $\begin{array}{c}\text { Diff. } \\
\text { from } \\
\text { baseline } \\
\text { (ppt) }\end{array}$ & $\begin{array}{l}\text { YOY } \\
(\%)\end{array}$ & $\begin{array}{c}\text { Diff. } \\
\text { from } \\
\text { baseline } \\
\text { (ppt) }\end{array}$ & $\begin{array}{l}\text { YOY } \\
(\%)\end{array}$ & $\begin{array}{c}\text { Diff. } \\
\text { from } \\
\text { baseline } \\
\text { (ppt) }\end{array}$ \\
\hline \multirow{3}{*}{ 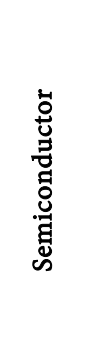 } & Baseline & 64,636 & 1.46 & 0.00 & 1.10 & 0.00 & 0.97 & 0.00 & 0.73 & 0.00 & 0.66 & 0.00 & 0.64 & 0.00 & 0.51 & 0.00 \\
\hline & $\begin{array}{c}\text { Scenario } \\
1\end{array}$ & 64,629 & 1.46 & 0.00 & 1.10 & 0.00 & 2.47 & 1.50 & 3.79 & 3.06 & 5.19 & 4.53 & 6.45 & 5.81 & 7.37 & 6.86 \\
\hline & $\begin{array}{c}\text { Scenario } \\
2\end{array}$ & 64,629 & 1.44 & -0.02 & 1.09 & -0.01 & 0.87 & -0.10 & 0.54 & -0.19 & 0.35 & -0.31 & 0.19 & -0.45 & -0.15 & -0.66 \\
\hline \multirow{4}{*}{ 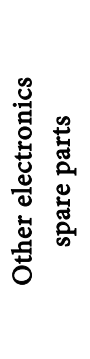 } & Baseline & 9063 & 1.45 & 0.00 & 0.72 & 0.00 & 0.70 & 0.00 & -0.24 & 0.00 & -0.35 & 0.00 & -0.29 & 0.00 & -0.93 & 0.00 \\
\hline & $\begin{array}{c}\text { Scenario } \\
1\end{array}$ & 9062 & 1.45 & 0.00 & 0.72 & 0.00 & 5.99 & 5.29 & 10.55 & 10.79 & 15.88 & 16.23 & 20.83 & 21.12 & 24.07 & 25.00 \\
\hline & $\begin{array}{c}\text { Scenario } \\
2\end{array}$ & 9062 & 1.36 & -0.09 & 0.65 & -0.07 & 7.59 & 6.89 & 13.97 & 14.21 & 20.94 & 21.29 & 27.04 & 27.33 & 30.80 & 31.73 \\
\hline & $\begin{array}{c}\text { Scenario } \\
3\end{array}$ & 9062 & 1.35 & -0.10 & 0.62 & -0.10 & 9.66 & 8.96 & 18.36 & 18.60 & 27.55 & 27.90 & 34.85 & 35.14 & 38.53 & 39.46 \\
\hline \multirow{3}{*}{ 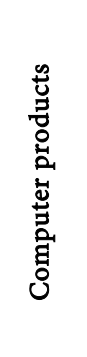 } & Baseline & 1672 & 2.83 & 0.00 & 1.44 & 0.00 & 1.23 & 0.00 & -0.64 & 0.00 & -0.94 & 0.00 & -0.87 & 0.00 & -1.79 & 0.00 \\
\hline & $\begin{array}{c}\text { Scenario } \\
2\end{array}$ & 1671 & 2.60 & -0.23 & 1.31 & -0.13 & 8.75 & 7.52 & 14.34 & 14.98 & 20.33 & 21.27 & 24.72 & 25.59 & 26.27 & 28.06 \\
\hline & $\begin{array}{c}\text { Scenario } \\
3\end{array}$ & 1671 & 2.59 & -0.24 & 1.27 & -0.17 & 10.86 & 9.63 & 18.56 & 19.20 & 25.96 & 26.90 & 30.60 & 31.47 & 31.67 & 33.46 \\
\hline \multirow{4}{*}{ 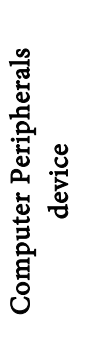 } & Baseline & 3844 & 1.40 & 0.00 & 1.09 & 0.00 & 1.10 & 0.00 & 0.66 & 0.00 & 0.61 & 0.00 & 0.63 & 0.00 & 0.32 & 0.00 \\
\hline & $\begin{array}{c}\text { Scenario } \\
1\end{array}$ & 3844 & 1.40 & 0.00 & 1.09 & 0.00 & 3.99 & 2.89 & 6.47 & 5.81 & 9.09 & 8.48 & 11.26 & 10.63 & 12.46 & 12.14 \\
\hline & $\begin{array}{c}\text { Scenario } \\
2\end{array}$ & 3844 & 1.36 & -0.04 & 1.06 & -0.03 & 4.97 & 3.87 & 8.45 & 7.79 & 11.82 & 11.21 & 14.26 & 13.63 & 15.29 & 14.97 \\
\hline & $\begin{array}{c}\text { Scenario } \\
3\end{array}$ & 3844 & 1.36 & -0.04 & 1.05 & -0.04 & 6.00 & 4.90 & 10.47 & 9.81 & 14.48 & 13.87 & 16.91 & 16.28 & 17.43 & 17.11 \\
\hline \multirow{4}{*}{ 吕 } & Baseline & 16,744 & 1.61 & 0.00 & 1.09 & 0.00 & 0.91 & 0.00 & 0.53 & 0.00 & 0.42 & 0.00 & 0.39 & 0.00 & 0.18 & 0.00 \\
\hline & $\begin{array}{c}\text { Scenario } \\
1\end{array}$ & 16,744 & 1.61 & 0.00 & 1.09 & 0.00 & 2.92 & 2.01 & 4.60 & 4.07 & 6.40 & 5.98 & 7.97 & 7.58 & 8.98 & 8.80 \\
\hline & $\begin{array}{c}\text { Scenario } \\
2\end{array}$ & 16,744 & 1.58 & -0.03 & 1.06 & -0.03 & 0.74 & -0.17 & 0.21 & -0.32 & -0.10 & -0.52 & -0.41 & -0.80 & -1.04 & -1.22 \\
\hline & $\begin{array}{c}\text { Scenario } \\
3\end{array}$ & 16,744 & 1.58 & -0.03 & 1.05 & -0.04 & 0.71 & -0.20 & 0.16 & -0.37 & -0.14 & -0.56 & -0.53 & -0.92 & -1.33 & -1.51 \\
\hline
\end{tabular}

Note: YoY refers to the percentage change from last year, and ppt refers to the percentage point. 
Table 3. The employment impacts of smart manufacturing on Taiwan's semiconductor and ICT industry.

\begin{tabular}{|c|c|c|c|c|c|c|c|c|c|c|c|c|c|c|c|c|}
\hline \multirow[b]{2}{*}{ Sector } & \multirow[b]{2}{*}{ Scenario } & $\begin{array}{l}\text { Year } \\
2015\end{array}$ & \multicolumn{2}{|c|}{$\begin{array}{l}\text { Year } \\
2019\end{array}$} & \multicolumn{2}{|c|}{$\begin{array}{l}\text { Year } \\
2020\end{array}$} & \multicolumn{2}{|c|}{$\begin{array}{l}\text { Year } \\
2021\end{array}$} & \multicolumn{2}{|c|}{ Year } & \multicolumn{2}{|c|}{ Year } & \multicolumn{2}{|c|}{ Year } & \multicolumn{2}{|c|}{ Year } \\
\hline & & $\begin{array}{c}\text { Bas } \\
\text { Year } \\
\text { (USD } \\
\text { million) }\end{array}$ & $\begin{array}{l}\text { YOY } \\
\text { (\%) }\end{array}$ & $\begin{array}{c}\text { Diff. } \\
\text { from } \\
\text { baseline } \\
\text { (ppt) }\end{array}$ & $\begin{array}{l}\text { YOY } \\
(\%)\end{array}$ & $\begin{array}{c}\text { Diff. } \\
\text { from } \\
\text { baseline } \\
\text { (ppt) }\end{array}$ & $\begin{array}{l}\text { YOY } \\
(\%)\end{array}$ & $\begin{array}{c}\text { Diff. } \\
\text { from } \\
\text { baseline } \\
\text { (ppt) }\end{array}$ & $\begin{array}{l}\text { YOY } \\
(\%)\end{array}$ & $\begin{array}{c}\text { Diff. } \\
\text { from } \\
\text { baseline } \\
\text { (ppt) }\end{array}$ & $\begin{array}{l}\text { YOY } \\
(\%)\end{array}$ & $\begin{array}{c}\text { Diff. } \\
\text { from } \\
\text { baseline } \\
\text { (ppt) }\end{array}$ & $\begin{array}{c}\text { YOY } \\
(\%)\end{array}$ & $\begin{array}{c}\text { Diff. } \\
\text { from } \\
\text { baseline } \\
\text { (ppt) }\end{array}$ & $\begin{array}{l}\text { YOY } \\
(\%)\end{array}$ & $\begin{array}{c}\text { Diff. } \\
\text { from } \\
\text { baseline } \\
\text { (ppt) }\end{array}$ \\
\hline \multirow{5}{*}{ 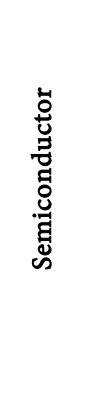 } & Baseline & 132,369 & 0.31 & 0.00 & -0.32 & 0.00 & -0.34 & 0.00 & -1.09 & 0.00 & -1.16 & 0.00 & -1.09 & 0.00 & -1.57 & 0.00 \\
\hline & $\begin{array}{c}\text { Scenario } \\
1\end{array}$ & 132,355 & 0.31 & 0.00 & -0.32 & 0.00 & -2.39 & -2.05 & -5.29 & -4.20 & -7.79 & -6.63 & -10.53 & -9.44 & -14.18 & -12.61 \\
\hline & $\begin{array}{c}\text { Scenario } \\
2\end{array}$ & 132,355 & 0.22 & -0.09 & -0.35 & -0.03 & -0.77 & -0.43 & -1.88 & -0.79 & -2.41 & -1.25 & -2.88 & -1.79 & -4.06 & -2.49 \\
\hline & $\begin{array}{c}\text { Scenario } \\
3\end{array}$ & 132,355 & 0.21 & -0.10 & -0.37 & -0.05 & -3.74 & -3.40 & -8.27 & -7.18 & -13.06 & -11.90 & -18.81 & -17.72 & -26.18 & -24.61 \\
\hline & Baseline & 40,545 & 0.34 & 0.00 & -0.56 & 0.00 & -0.55 & 0.00 & -1.70 & 0.00 & -1.80 & 0.00 & -1.69 & 0.00 & -2.44 & 0.00 \\
\hline \multirow{3}{*}{ 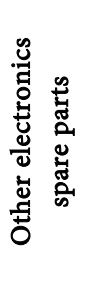 } & $\begin{array}{c}\text { Scenario } \\
1\end{array}$ & 40,541 & 0.34 & 0.00 & -0.56 & 0.00 & -0.98 & -0.43 & -2.81 & -1.11 & -4.13 & -2.33 & -5.99 & -4.30 & -9.49 & -7.05 \\
\hline & $\begin{array}{c}\text { Scenario } \\
2\end{array}$ & 40,541 & 0.22 & -0.12 & -0.65 & -0.09 & -1.46 & -0.91 & -3.91 & -2.21 & -6.34 & -4.54 & -9.87 & -8.18 & -15.31 & -12.87 \\
\hline & $\begin{array}{c}\text { Scenario } \\
3\end{array}$ & 40,541 & 0.21 & -0.13 & -0.68 & -0.12 & -1.47 & -0.92 & -4.21 & -2.51 & -7.38 & -5.58 & -12.46 & -10.77 & -19.81 & -17.37 \\
\hline \multirow{5}{*}{ 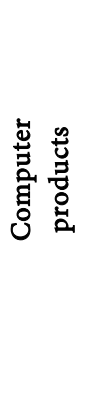 } & Baseline & 3001 & 1.39 & 0.00 & 0.23 & 0.00 & 0.06 & 0.00 & -1.49 & 0.00 & -1.73 & 0.00 & -1.67 & 0.00 & -2.43 & 0.00 \\
\hline & $\begin{array}{c}\text { Scenario } \\
1\end{array}$ & 3001 & 1.40 & 0.01 & 0.23 & 0.00 & -2.12 & -2.18 & -6.35 & -4.86 & -10.32 & -8.59 & -15.26 & -13.59 & -21.80 & -19.37 \\
\hline & $\begin{array}{c}\text { Scenario } \\
2\end{array}$ & 3001 & 1.20 & -0.19 & 0.13 & -0.10 & -2.95 & -3.01 & -8.38 & -6.89 & -14.42 & -12.69 & -22.08 & -20.41 & -31.30 & -28.87 \\
\hline & $\begin{array}{c}\text { Scenario } \\
3\end{array}$ & 3001 & 1.19 & -0.20 & 0.09 & -0.14 & -3.69 & -3.75 & -10.47 & -8.98 & -18.79 & -17.06 & -29.39 & -27.72 & -41.44 & -39.01 \\
\hline & Baseline & 14,202 & 0.32 & 0.00 & -0.35 & 0.00 & -0.30 & 0.00 & -1.24 & 0.00 & -1.31 & 0.00 & -1.21 & 0.00 & -1.82 & 0.00 \\
\hline \multirow{3}{*}{ 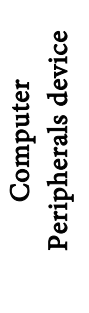 } & $\begin{array}{c}\text { Scenario } \\
1\end{array}$ & 14,201 & 0.32 & 0.00 & -0.35 & 0.00 & -1.40 & -1.10 & -3.63 & -2.39 & -5.39 & -4.08 & -7.58 & -6.37 & -11.11 & -9.29 \\
\hline & $\begin{array}{c}\text { Scenario } \\
2\end{array}$ & 14,201 & 0.23 & -0.09 & -0.42 & -0.07 & -1.84 & -1.54 & -4.60 & -3.36 & -7.26 & -5.95 & -10.83 & -9.62 & -16.10 & -14.28 \\
\hline & $\begin{array}{c}\text { Scenario } \\
3\end{array}$ & 14,201 & 0.22 & -0.10 & -0.44 & -0.09 & -2.21 & -1.91 & -5.60 & -4.36 & -9.34 & -8.03 & -14.77 & -13.56 & -22.49 & -20.67 \\
\hline \multirow{4}{*}{ 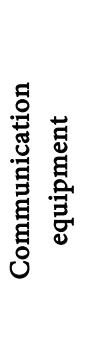 } & Baseline & 37,974 & 0.51 & 0.00 & -0.36 & 0.00 & -0.43 & 0.00 & -1.39 & 0.00 & -1.49 & 0.00 & -1.42 & 0.00 & -2.01 & 0.00 \\
\hline & $\begin{array}{c}\text { Scenario } \\
1\end{array}$ & 37,970 & 0.51 & 0.00 & -0.36 & 0.00 & -1.92 & -1.49 & -4.51 & -3.12 & -6.59 & -5.10 & -8.99 & -7.57 & -12.57 & -10.56 \\
\hline & $\begin{array}{c}\text { Scenario } \\
2\end{array}$ & 37,970 & 0.42 & -0.09 & -0.44 & -0.08 & -0.96 & -0.53 & -2.37 & -0.98 & -3.05 & -1.56 & -3.74 & -2.32 & -5.35 & -3.34 \\
\hline & $\begin{array}{c}\text { Scenario } \\
3\end{array}$ & 37,970 & 0.41 & -0.10 & -0.46 & -0.10 & -1.06 & -0.63 & -2.55 & -1.16 & -3.27 & -1.78 & -4.24 & -2.82 & -6.26 & -4.25 \\
\hline
\end{tabular}

Note: YoY refers to the percentage change from last year, and ppt refers to the percentage point. 
will be reduced to 62,000 in 2025 , which is 24.61 percentage points lower than the baseline. The Scenarios 1 and 2 are 12.61 and 2.49 percentage points lower than the baseline, respectively, and the employment reduce to 88,000 and 119,000 respectively. Due to the shorter and smaller injections of private investment in Scenario 2, the manpower saving is not as much as in Scenario 1. Compared with the growth contribution of the semiconductor industry production value in Table 2, the per capita output value in the three scenarios is still significantly higher than that without the smart manufacturing.

In the computer and related electronic component sector, information electronics account for nearly $47 \%$ of Taiwan's total exports (Bureau of Foreign Trade, 2020). From the baseline results in Table 2, this sector will grow by $1.79 \%$ to $1.44 \%$ annually from 2020 to 2025 . It is expected that by 2025 , Scenarios 1,2 , and 3 will be 22.44, 28.06, and 33.46 percentage points higher than the baseline, respectively. It implies that the smart manufacturing brings a significant contribution to the production value of the ICT and computer industry.

In terms of the baseline forecast of the computer peripheral equipment sector, it is expected to grow $0.32 \%$ to $1.09 \%$ annually from 2020 to 2025 . By 2025, Scenarios 1,2 , and 3 will be 12.14, 14.97, and 17.11 percentage points higher than the baseline, respectively. The results presented are similar to the computer product sector. It is clear that under the maturity of products, both the public and private investment in smart manufacturing can improve the production value of the computer peripheral equipment industry, and the investment benefit of the private sector is slightly greater than that of the public sector.

The production value of the communications equipment sector will grow by $0.18 \%$ to $1.09 \%$ per year from 2020 to 2025 . It is expected that by 2025 , Scenario 1 will be 8.8 percentage points higher than the baseline, and Scenarios 2 and 3 will be 1.22 and 1.51 percentage points lower than the baseline, respectively. The communication equipment mainly includes telephone exchange equipment, fax machine equipment, pagers, network bridges, routers, gateways, radio and television transmission equipment, local and wide area network communication equipment, modems, etc. The application of smart manufacturing is not critical, and private enterprises invest in Scenario 2 is mostly concentrated on their production automation and capacity enhancement. In comparison to Scenario 1 which is mostly investment on AI research platforms or innovation research centers, the benefits and rate of return will be lower in Scenarios 2 and 3.

The production value of other electronic components sector will grow by $-0.93 \%$ to $0.72 \%$ annually from 2020 to 2025 . It is expected that by 2025 , Scenarios 1,2 , and 3 will be $25,31.73$, and 39.46 percentage points higher than the baseline, respectively. The simulation results are similar to those of the computer product sector. It is obvious that the introduction of smart manufacturing brings a healthy contribution to the production value of the industry as their products are getting matured. With regard to the public or private investment, results shows that the output efficiency increase dramatically as well.

In terms of the impact of employment on the ICT industry, as shown in Table 
3 , the baseline results suggest that total employment will decrease by $2.43 \%$ to $0.23 \%$ per year from 2020 to 2025 . The growth rate is getting smaller every year, and becomes negative after 2022. It is expected that by 2025 , Scenarios 1,2 , and 3 will be 19.37, 28.87, and 39.01 percentage points lower than the baseline, respectively. Thus, the introduction of smart manufacturing reduces the labor demand of the industry significantly and its manpower savings are obvious. In terms of the baseline forecast of the computer peripheral equipment sector, it is expected that the annual employment will also decline by $-0.3 \%$ to $-1.82 \%$ from 2020 to 2025 . It is expected that by 2025 , Scenarios 1,2 , and 3 will be $9.29,14.28$, 20.67 percentage points lower than the baseline, respectively. Similar results can be found in the computer product sector. Obviously, as the computer products enter maturity, the employment of computer and peripheral equipment industry will decline which can be quite a challenge for manufacturing workers.

In terms of employment for the communications equipment sector, it will decline by $0.36 \%$ to $2.01 \%$ per year from 2020 to 2025 . It is expected that by 2025 , Scenario 1 will be 10.56 percentage points lower than the baseline, and Scenarios 2 and 3 will be 3.34 and 4.25 percentage points less than the baseline, respectively. It is obvious that the manpower saving is the public investment scheme will be greater than the saving led by private investment. It is estimated that by 2025 , employment reduction will be 36,000 people in the baseline and 27,000 in Scenario 1 . The employment of other electronic component sectors will decrease by $0.55 \%$ to $2.44 \%$ each year from 2020 to 2025 . It is expected that by 2025 , Scenarios 1,2 , and 3 will be $7.05,12.87$, and 17.37 percentage points lower than the baseline, respectively. The results are similar to those of other ICT industries. It is clear that the introduction of smart manufacturing will bring in a significant change in employment structure and labor saving effect in the industry, no matter the investment comes from the public or private sector. Moreover, compared with the production value in Table 2 , the per capita production value of the industry has increased significantly. It shows that smart manufacturing delivers benefits to the ICT industries though labor saving and productivity enhancement.

Our findings are in accordance with the previous empirical studies which indicate that the emergence of smart technologies will most likely cause considerable shifts in the structure of the economy and employment. While manufacturing using more of AI will have a positive impact on production values, however it has a negative impact on employment with potential risks from structural labor market problems.

\section{Conclusions and Suggestions}

In this paper, using dynamic CGE model of MONASH-type and Taiwan's input-output tables to capture the supply-chain interdependence and resource constraints, we present the economy-wide assessment of government policies and private companies' investment in smart manufacturing, as well as the impact on the output and employment of Taiwan semiconductor and ICT industry. 
These findings are in line with previous studies in general.

The simulation results show that under the government's policies and private companies' investment in the development of artificial intelligence, the output growth of the semiconductor and ICT industry has increased significantly, and employment demand has significant benefits in labor-saving. Smart manufacturing is the effective adaptation strategy for declining birthrate and labor shortage in Taiwan. However, establishing smart manufacturing is not a short-term task. In addition to the investment of capital and the accumulation of time, it is also necessary to establish a complete industrial supply chain for industrial upstream suppliers and downstream customers, and develop a consensus on smart manufacturing.

\subsection{Suggestions}

In order to scale-up the benefits of smart manufacturing to industries, this study proposes three suggestions as follows.

First, the government and enterprises need to cooperate and play their roles, respectively. Artificial intelligence contains too many aspects, and individual companies cannot build up all of the smart manufacturing. Therefore, the government should focus on the cultivation of AI talents and establish infrastructure. In terms of talent development, the industry, schools, and academia must actively develop talents and abilities which include software programming, algorithms, programming the machine control software, and hardware mechanical design. This can be trained through government incentives, and combined with the practical needs of private enterprises, so that the production and education can be fully combined to reduce the gap between education and industry.

Second, smart manufacturing is broad and deep, so companies need to plan from a macro perspective, but before implementation, companies should review the resources owned by the enterprise, then start from a small area. It means that starting from the automation of machine equipment, then the automation of the production line, the intelligence of the entire production field, and finally integrated with the supplier's material situation and the client's market information. That is, before reaching Industry 4.0, it can reach Industry 3.5 for transition.

Third, excellent AI talents and multinational manufacturers are the objects of international competition, all countries try to recruit talents or manufacturers with preferential incentives and excellent technical talents also need to be able to practice. Therefore, the government should construct a robust and open development environment, attract international technical talents and establish tax incentives and other mechanisms to allow enterprises to design a suitable smart manufacturing model. At the same time, it also allows excellent talents to find a stage to play.

\subsection{Research Limitations}

Our findings provide solid and supporting evidence to the investment policies on $\mathrm{AI}$ in manufacturing sectors. The question is how to address the challenge of 
unemployment arising from AI investment. In order to tackle the earning losses from unemployment persistence, linking the changes of labor productivity with trends in income inequality among different sector, occupations and age/gender cohorts should be an important avenue for future research. Although, our modeling effort and scenario settings yield predictions that are supported by experts across the private sectors, detailed industry-wide survey data should also be introduced to verify these scenario settings. Moreover, the database used in this study is the Input-Output Tables compiled by the government on a 5-year interval. In the future, it should be updated to capture the fast-changing industrial structure.

\section{Acknowledgements}

This research is supported by the Center for Sustainability Science, Academia Sinica of Taiwan under the Project No. AS-SS-107-02. The authors would like to thank the editor and two anonymous reviewers for their helpful comments.

\section{Conflicts of Interest}

The authors declare no conflicts of interest regarding the publication of this paper.

\section{References}

Acemoglu, D., \& Restrepo, P. (2019). Robots and Jobs: Evidence from US Labor Markets. National Bureau of Economic Research Working Paper, No. w23285. Journal of Political Economy. https://doi.org/10.1086/705716

Bureau of Foreign Trade (2020). Key Indicators in Trade Statistics, Republic of China. https://www.trade.gov.tw/Pages/List.aspx?nodeID $=1374$

Chang, C. C., Hsu, S. H., Lin, H. C., Lee, D. H., Chen, C. C., \& Wu, C. H. (2018). Enhanced GEMTEE (General Equilibrium Model for Taiwan Economy and Environment) for IAM Framework: An Integrated Computable General Equilibrium Model and Database for Appraising Policies toward Sustainable Development. Center for Sustainability Science, Academia Sinica.

Chen, P. C., Chang, C. C., \& Chen, C. N. (2020). Regional Projections and Analysis of Future Long-Term Care Needs of Taiwan. Journal of Social Sciences and Philosophy.

Chen, P. C., Chang, C. C., Chen, C. N., Hsu, S. M., \& Lin, H. C. (2015). Projections of Future Long-Term Care Needs of an Aging Population of Taiwan-An Application of GEMTEE. Journal of Population Studies, 51, 43-93.

Dauth, W., Findeisen, S., Südekum, J., \& Wößner, N. (2017). German Robots-The Impact of Industrial Robots on Workers. CEPR Discussion Papers No. 12306.

Directorate-General of Budget, Accounting and Statistics (2014a). National Wealth 2014. Taipei: Directorate-General of Budget, Accounting and Statistics.

Directorate-General of Budget, Accounting and Statistics (2014b). The Report on 2011 Input-Output Tables. Taipei: Directorate-General of Budget, Accounting and Statistics.

Directorate-General of Budget, Accounting and Statistics (2014c). National Accounts Yearbook 2014. Taipei: Directorate-General of Budget, Accounting and Statistics.

Dixon, P. B., \& Parmenter, B. R. (1996). Chapter 1: Computable General Equilibrium 
Modelling for Policy Analysis and Forecasting. In H. M. Amman, D. A. Kendrick, \& J. Rust (Eds.), Handbook of Computable Economics (Vol. 1). Amsterdam: North Holland. https://doi.org/10.1016/S1574-0021(96)01003-9

Dixon, P. B., \& Rimmer, M. T. (2002). Dynamic General Equilibrium Modelling for Forecasting and Policy: A Practical Guide and Documentation of MONASH. Amsterdam: Elsevier. https://doi.org/10.1108/S0573-8555(2001)256

Dixon, P. B., \& Rimmer, M. T. (2009). Forecasting with a CGE Model: Does It Work? Centre of Policy Studies/IMPACT Centre Working Papers g-197, Victoria University, Centre of Policy Studies/IMPACT Centre.

Frey, C. B., \& Osborne, M. A. (2017). The Future of Employment: How Susceptible Are Jobs to Computerization? Technological Forecasting and Social Change, 114, 254-280. https://doi.org/10.1016/j.techfore.2016.08.019

Graetz, G., \& Michaels, G. (2018). Robots at Work. The Review of Economics and Statistics, 100, 753-768. https://doi.org/10.1162/rest a 00754

Harrison, W. J., \& Pearson, K. R. (1996). Computing Solutions for Large General Equilibrium Models Using GEMPACK. Computational Economics, 9, 83-127.

https://doi.org/10.1007/BF00123638

Hsu, S. H., Lin, K. J., Su, H. P., Lin, H. S., \& Lee, D. H. (2006). Forecasting Changes in Taiwan's Industrial Structure Using a Dynamic CGE Approach. Taiwan Economic Forecast and Policy, 36, 1-46.

Lin, H. C., Lee, H. L., Hsu, S. M., Lin, K. J., Lee, D. H., Chang C. C., \& Hsu, S. H. (2015). Baseline Forecasting for Taiwan's Population in the Face of Low Fertility Rate and Aging Problems. Taiwan Economic Forecast and Policy, 46, 113-156.

Liou, R. W., Hsu, S. M., Lin, H. C., Hsieh, T. Y., Chang, C. C., \& Hsu, S. H. (2018). An Economy-Wide Impact Analysis of Increasing Government Infrastructure Investment on Macro-Economy, Fiscal Balance and Income Distribution: A Dynamic Computable General Equilibrium. Taiwan Economic Forecast and Policy, 48, 41-78.

Smart Electronics Industry Project Promotion Office (2019). Semiconductor Industry Status Quo.

https://www.sipo.org.tw/industry-overview/industry-state-quo/semiconductor-industr y-state-quo.html 